DOI: 10.33184/YVDK-2021-04-30.64

Т.Д. Шабанова (проф. БГПУ им. Акмулль, г. Уфа), Л.А. Саубанова (асп. БГПУ им. Акмулль, г. Уфа)

\title{
ИЗМЕНЕНИЕ ЗНАЧЕНИЯ ГЛАГОЛА В АНГЛИЙСКИХ РЕКЛАМНЫХ СЛОГАНАХ
}

В статье рассматривается современная проблема лингвистики -изменение значения глагола в слоганах. Изменения значений глагола связаны с такими когнитивными прочессами, как смена типов когнитивного пространства, когнитивная метонимия. Основная идея состоит в том, что некоторые стандартные языковые прочессы лежат в основе семантических модулячиий.

Ключевые слова: каузативная конструкция, когнитивная метонимия, слоган.

The article deals with the present day problem of linguistic explanation of modulation of verb meaning in slogans. Modulations of verb meaning are related to such cognitive processes as change of cognitive space types, cognitive metonymy. The basic idea is that certain standard language processes underlie semantic modulations.

Keywords: causative construction, cognitive metonymy, slogan.

The phenomenon of the slogan is closely connected with the problems of advertisement from the point of view of its syntactic structure, contents, laws of communication and cognitive mechanisms which impact the agonist. Slogan has a summing up role and usually is at the end of the advertising message. Slogan stands next to the name of advertiser or advertised trademark - its brand. Slogan concludes everything which is said and shown in an advertisement. It performs the function of connection between the separate advertisements of general advertising company. For example, in the text of advertisement of online shop Ebay we may find the following: When you're ready - come and get it. It is a great big world and it can be all yours. Here, and only here. Shop the World. One can easily distinguish the text of advertisement as description of the online shop: 
'When you're ready - come and get it. It is a great big world and it can be all yours. Here, and only here'. The slogan Shop the World is connected between all components of the advertising text and the result of everything that have been mentioned.

The pragmatic function of advertising slogan is not limited to the information about the advertised object. The advertising slogan from the point of view of pragmatics has the following descriptions: 1) axiological description (positive assessment of explicit or implicit character); 2) communicative (promotes the contact between an advertiser and a potential customer); 3) pragmatic (slogan is targeted to a certain audience); 4)particular illocutionary force (direct or implied imperative orientation); 5) manipulative (different ways of manipulations, mystifications and marketing strategy); 6) autonomous (slogan can be used separately from the advertising text) [Kolokolceva 2011: 159]. Hence, advertising slogan is not simply a short formulation of an advertising idea, but an effective instrument of motive to make a purchase, as its main target is providing of extralinguistic impact on the addressee (agonist). In the example of the slogan, Shop the World all the above characteristics are used and aimed at influencing the addressee (agonist).

This slogan can be regarded as a syntactic form of the cognitive construction (imperative construction), which can be considered an exponent of situational cognitive metonymy [Semyonova 2019]. The slogan Shop the World directly affects the man's sub consciousness and evokes corresponding emotions, because the slogan is an example of using a strong stylistic device with great pragmatic potential. Cognitive metonymy in this case is formed according to the model of "container" (the world) instead of its contents (variety of possible purchases). In the analyzed example, the syntactic structure of the slogan is characterized by a one-member verb sentence, which is the imperative mood from the point of view of morphological categories.

2000 analyzed examples of advertising texts shoed that the most frequent structures are verbal imperative constructions - 52\%, one-member nominative sentences - $28 \%$, two-member sentences $20 \%$.

Pragmatic orientation of the slogan plays an important role in its effectiveness because of its wholesome value. Thus, as an actualized value in the slogan there can be focused an item that 
mostly attracts the consumer's attention at particular time period. Thus the expression "Diagnose Your Patients" is a slogan of the firm Canon and is a key to a wholesome concept of customer care. The slogan of fast food restaurants Subway "Eat Fresh" can be regarded in the same way. The slogan of Ebay online shop "Shop the World" is the key to the concept of unlimited power of the consumer; The slogan "Feel Intelligent Drive" of the the Mercedes Benz s-class brand is a hint to the authority of the company; The slogan "Wake Up and Drive" of the Mitsubishi brand is the key to concept of comfort and luxury; the slogan "Be the First to Know" of the IBM company is a key to leadership in cloud technology; the slogan "Have Fun Out There" of the Jeep brand is a key to the value of carefree life. Thus, these slogans, being causative constructions, are a cognitive situational metonymy type, which is based on the part-whole cognitive metonymic mechanism.

As a rule, any advertisement creates an image of idyllic lifestyle, which is very easy to achieve - just buy the advertised product. This mythology of advertising is precisely noticed by the modern writer V. O. Pelevin: "Usually there advertised simple human happiness but not the products. Any advertisement shows equally happy people but this happiness is acquired in different ways. That is why a man goes to the store not to buy things, but to buy happiness" [Pelevin 1999]. A cognitive metonymy is just the very means to express the idea. Happiness in this case can be regarded as a wholesome valuable concept, as something great and positive, the product - as the key to this happiness, and the name of the product - as a cognitive situational metonymy.

The cognitive metonymy is used in all language spheres and performs specific functions within each of them. In the study of slogans, it was noted that cognitive metonymy according to the 'statesource of state' model is mostly frequent. It is this type that allows to achieve maximum impact on a potential customer and makes him buy advertised products. Thus, the transference 'state- $>$ source of state' can be illustrated by such advertising slogans: "Coffee that Inspires" in Starbucks advertising (state - inspires, source of state - Coffee), "Don't just listen to experts. Become one" in Discovery channel advertising (source of state - Discovery channel, state - Become one (be an expert)), "Have a Break, Have Kit Kat" in Kit Kat advertising (state Have a Break and relax, source of state-Kit Kat). Thus using this 
type of slogan model, a positive image of the advertised product is achieved.

It should be noted that in creating positive images of advertising slogans we can find a lot of cases of situational metonymy. For example, just in one phrase from Sony "make. believe " there is hidden the whole cognitive situation. One can find the explanation of this slogan in Sony site: the scheme illustrates correlation between the elements of the slogan.

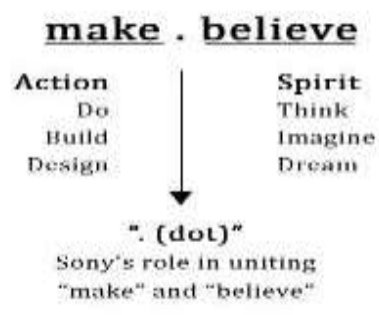

In the interpretation of the creators of advertising make. believe implies concretization of actions, that make is an action that requires some effort, believe is creative thinking, the point between the two words is the role of Sony, where Sony can connect all our dreams and efforts together and realize our plans.

Thus, certain technologies are used to create a positive image of the advertised product: metonymic transference, situational metonymy, pragmatic orientation, value information. The advertising slogan correlates with causation, as it actualizes the causation of informative modifications. The antagonist makes an attempt to change the level of "enlightenment, knowledge, attitude" of the agonist in such way as to extract maximum benefit [Popova 2005].

An advertising slogan is a powerful means of influencing the minds of potential consumers. They most absorb in themselves all the features of advertising as a type of discourse: conciseness, high expressiveness, limited time or space, purposefulness, addressing to a mass audience - which determines their high manipulative potential.

Advertising slogans are filled with causative (causal) meanings, which determines not only the information richness of these slogans, but also the variety of communicative attitudes. And one of the main motive that underlies in the advertising slogan is the motive for personal benefit [Golman 1991: 64]. 
Thus, the study of semantic processes that underlie modulation in the meaning of verbs shows that the semantic modulations are based on systemic standard language processes and cognitive metonymic transference is one of them.

\section{REFERENCES}

1. Gol'man I. A., Dobrobabenko N.S. Praktika reklamy: desyat' urokov dlya sovremennogobiznesmena. -Novosibirsk, 1991.- 142 s.

2. Kolokol'ceva T. N. Slogan kak klyuchevoj komponent reklamnogo teksta // Reklamnyj diskurs i ego konstitutivnye priznaki; pod red. Kolokol'cevoj. - M.: Nauka, 2011. - s. 147-170.

3. Pelevin V. O. Generation «P». - M.: Vagrius, 1999. - 302s.

4. Popova E.S. Reklamnyj tekst i problemy manipulyacii: avtoref. dis. na soisk. uchen. step. kand. filol. nauk (10.02.01); Ural. gos. un-t im. A. M. Gor'kogo. - Ekaterinburg, 2005. $-27 \mathrm{~s}$.

5. Semenova P.V. Kognitivno-semanticheskaya model' hudozhestvennogo prostranstva angloyazychnogo proizvedeniya (na materiale romana Iena Mak'yuena "Atonement"): avtoref. dis. na soisk. uchen. step. kand. filol. nauk(10.02.04); BGPU im. Akmully.- Ufa, 2019. - 22s.

\section{ЛИТЕРАТУРА}

1. Гольман И. А., Добробабенко Н.С. Практика рекламы: десять уроков для современного бизнесмена. -Новосибирск, 1991.- 142 с.

2. Колокольцева Т. Н. Слоган как ключевой компонент рекламного текста // Рекламный дискурс и его конститупивные признаки; под ред. Колокольцевой. - М:: Наука, 2011. — с. 147-170.

3. Пелевин В. О. Generation «П». - М.: Вагриус, 1999. - 302 c.

4. Попова Е.С. Рекламный текст и проблемы манипуляции: автореф. дис. на соиск. учен. степ. канд филол. наук (10.02.01); Урал. гос. ун-т им. А. М. Горького. - Екатеринбург, 2005. -27 с.

5. Семенова П.В. Когнитивно-емантическая модель художественного пространства англоязычного произведения (на материале романа Иэна Макьюэна "Atonement"): автореф. дис. на соиск. учен. степ. канд. филол. наук (10.02.04); БГПУ им. Акмуллы.-Уфа, 2019. - 22с.

С СаубановаЛ.А., Шабанова Т.Д, 2021 г. 